ested in this rather puzzling question may study it to see whether there is anything in the theory suggested here.

H. J. Conn, R. S. BreEd

Agricultural Experiment Station, GeneVA, N. Y.

\section{PENSIONS FOR GOVERNMENT EMPLOYEES}

The American Association for Labor Legislation calls attention to the very serious evils arising from the lack of a pension system in the government bureaus at Washington. They say: "It is now reported that of a total of 878 employees in one federal bureau in Washington, 303 are over 65 years old, 104 over 75, and 29 over 80 . The Treasury Department alone has 1,000 aged who average only 25 per cent. efficiency-1,000 drawing full pay for work that could be done by $250 . "$

This is a matter which concerns scientific men. I remember several years ago calling on one of the most eminent zoologists in the $\mathrm{Na}$ tional Museum. I found that he was writing all his letters by hand, because the stenographer assigned to him was too old to do the work. He explained that of course he could not, or would not dismiss her; but as a result he was left without the assistance he should have had. I recall a scientific assistant, retained by a bureau long after he had ceased to be able to do anything of value, but required to spend his days at his desk. No one would have thought of turning him away unless he could be adequately provided for. The effect of these conditions on the progress of science is obvious and lamentable.

It appears that there is now a bill before Congress, providing for retirement on part pay at 65 , the employee contributing $2 \frac{1}{2}$ per cent. of wages, the government the rest. It should certainly be supported.

\section{T. D. A. Cockerell}

UNIVERSITY OF Colorado, March 1, 1920

\section{THE RECENT AURORAS}

The Weather Bureau is compiling observations of the auroras of March 22-23, 23-24, and 24-25, 1920, as seen in the United States, or elsewhere, with a view to publishing a detailed account of this remarkable display in the March, 1920, issue of the Monthly Weather Review. It is hoped that those who observed an aurora on any of the dates mentioned will notify the bureau, and if details were noted will send copies of their notes. Information about any display which may be seen on April 18, 27 days after the brilliant night in March, or auroras observed on other dates in 1919 or 1920 will also be appreciated. Communications should be addressed to "Editor, Weather Bureau, Washington, D. C.," and should reach Washington by the end of April.

Charles F. Brooks, Meteorologist-Editor

\section{QUOTATIONS \\ CIVIL SERVICE PENSIONS}

AFTER years of half-hearted consideration Congress seems about to pass a bill for the retirement and pensioning of employees in the federal service. It will be applicable only to those in the classified service, about 300,000 in all. It is a measure of justice and at the same time a measure of economy, for the government hasn't been heartless enough to turn the superannuated loose. Thousands of them retain their places, but do little or no work.

The government retires employees in the military and kindred services. It ought to set a similar. standard for faithful civil employment. The retirement age in the army is sixty-four, and in the navy sixty-two. Taking into consideration the easier conditions of civil employment, the bill which has just passed the Senate fixes seventy as the civil retirement limit. The allowances will vary according to length of service, from thirty years down to eighteen years. Persons disabled through disease or injury in the line of duty may be retired before reaching seventy.

Another distinction is to be made between civil and military beneficiaries. An annuity assessment of $2 \frac{1}{2}$ per cent. will be levied annually on the salaries of civil employees until a retirement fund is accumulated. This assess- 